\title{
Physicians debate tax reforms at CMA annual meeting
}

Cite as: CMAJ 2017 September 11;189:E1159-60. doi: 10.1503/cmaj.1095483

Posted on cmajnews.com on Aug. 21, 2017, and updated on Aug. 30, 2017.

$\mathrm{T}$ hough many Canadian doctors have joined forces to oppose the federal government's proposal to reduce the tax-saving benefits of incorporation, not all physicians are in agreement on this issue. At a session on the topic at the Canadian Medical Association's (CMA) annual general council, some doctors, while admitting they were reluctant to speak out against the majority, said fighting the government over taxes might not be in the best interest of either the medical profession or the public.

"One of the ironic consequences of opposing these tax reforms is that we are advocating against collecting revenue that can be invested directly in health care, paid by those who are most able to pay," said Dr. Vanessa Brcic of British Columbia.

Many physicians incorporate their practices to offset the risks and expenses of self-employment. Also, because they don't have pensions or benefits, like salaried employees, they rely on paying lower rates of tax to fund their retirements and to cover unpaid time off for reasons such as illness or maternity leave.

But according to Dr. Hasan Sheikh of Ontario, incorporation is a "bad system for retirement savings." Instead of fighting to keep tax benefits, physicians should instead advocate for access to pensions and benefits, he said. "Let's find a way to align ourselves with our patients who don't have access to those things so we can all be on the same page, and advocate for our patients as we advocate for ourselves."

The fact that many Canadians in the workforce don't have paid sick leave, pensions or other benefits was brought up by

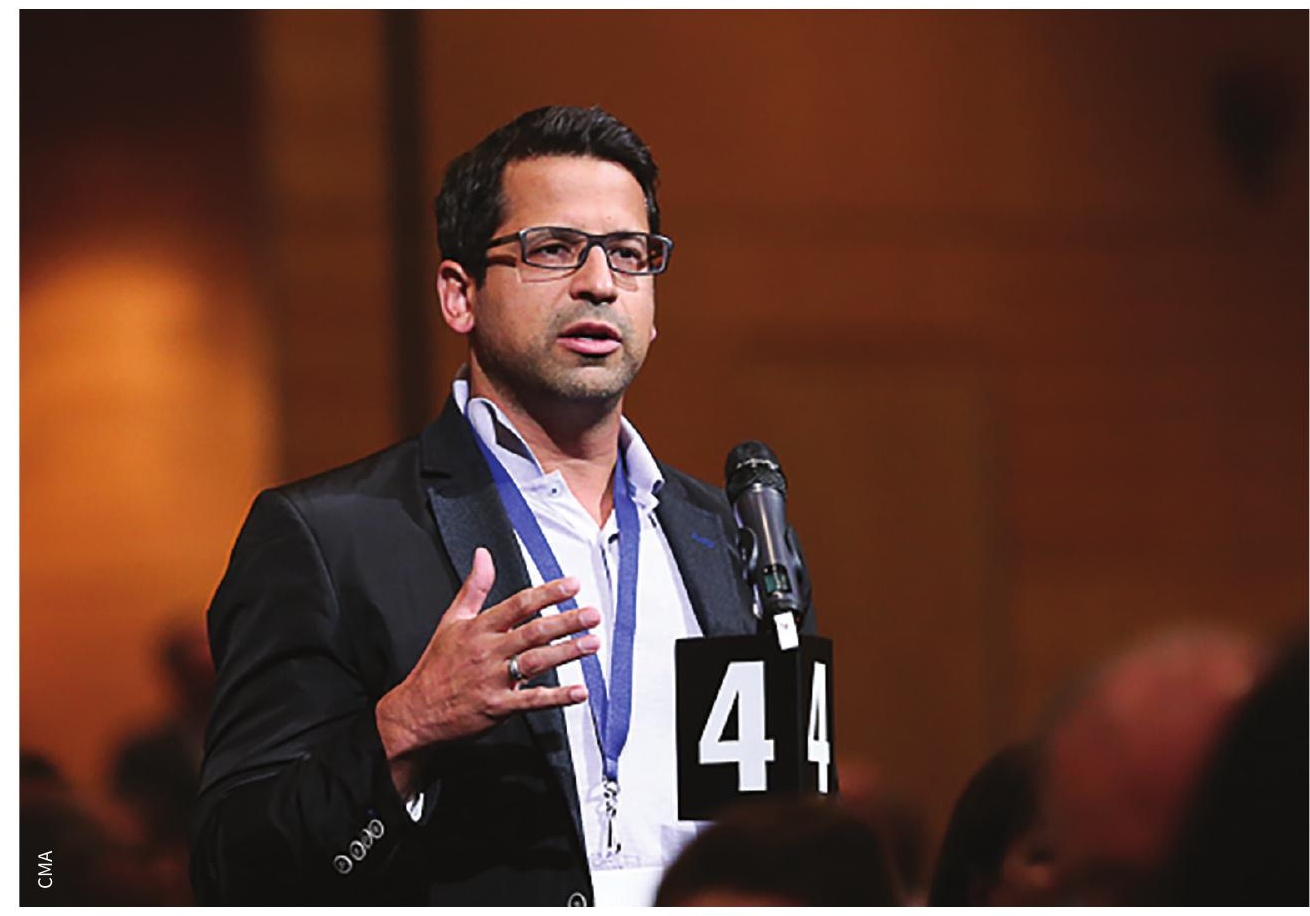

Physicians were eager to share their opinions on the federal government's proposed tax reforms.

several doctors. Others noted that physicians are a privileged group, among the top 5\% of earners in Canada, and should pay their fair share of taxes.

Still, most of the physicians who stood to comment on this issue at the session were opposed to the government's proposal. They said it could potentially lead to numerous problems - for doctors, for patients and for the health care system.

"These changes are just too sudden," said Dr. Nadia Alam of Ontario. "You can't make tax reform of this scale in this fashion in 75 days. It just doesn't work. It creates chaos."

According to Dr. Shawn Whatley, president of the Ontario Medical Association, it will ultimately be patients who suffer if physicians are "attacked" with tax reform. "You cannot make a radical change to the fundamentals of the economics of health care without impacting patient care," he said.

One physician suggested that reducing physician incomes, and their ability to retire, will only lead to more pressure during contract negotiations with provincial governments, who will then be forced to ask the federal government for more money. Another suggested that advocating for Canada's 85000 physicians to gain access to defined pension plans would be naive because of the high costs. Dr. Robert Davies of Alberta said providing tax advantages for small businesses levels the playing field with salaried employees 
who have a "host of untaxed benefits," so the government's proposed reforms don't make sense.

"Their proposal doesn't correct an inequity," he said. "In fact, it creates one."

Dr. Carrie Kollias shared a personal story to express her concerns. When she moved to rural Alberta to work as an orthopedic surgeon, her husband left a teaching position that would have given him a pension. Many people in similar situations rely on the doctor in the family to fund their spouse's retirement as well, she said.

"I think there will be a problem with retention and recruitment of all physicians in rural areas," she said.

Earlier in the day at the CMA meeting, the topic of the proposed tax reforms came up after a speech by Dr. Jane Philpott, the federal minister of health. Dr. Gigi Osler of Manitoba, CMA president-elect, noted that incorporated physicians assume the risk of establishing offices and clinics, employing staff and purchasing equipment.
"Canadian doctors care deeply about patients and about population health, but the government's proposal on the taxation of incorporated businesses has caused great concern among our members as well as the small business community," said Osler. "What assurances can you give us that the government will take our concerns into serious consideration?"

Philpott responded by assuring the CMA delegates that the government is indeed taking their concerns seriously. "I absolutely believe doctors need to be fairly paid for the very important work they do for society," said Philpott.

However, she cautioned against passing judgment on the government's proposal based on emotion or false stories circulated on social media. She encouraged physicians to read the 63-page document from the federal department of finance so they fully understand what is being proposed.

"This really is, actually, about fairness," she said.
The current system allows only some doctors to reduce their tax burdens, said Philpott, such as physicians with children aged 18-24 or those with spouses who have much lower incomes. She noted that no such benefit is granted to unmarried doctors or those without children, who will have to pay much higher taxes.

“That doesn't seem fair," said Philpott.

Philpott's remarks were not well received by many in attendance. Some immediately took to social media, saying that the health minister was "turning her back on physicians" and that doctors were indeed well informed and "do know the facts."

This sentiment was echoed during the debate later in the day. One doctor said he was disappointed that Philpott had dismissed their concerns as emotional, uninformed feedback. Another physician, Dr. Bradley Fritz of BC, said he "took a little umbrage" at the health minister for "telling us we can't read."

Roger Collier, CMAJ 